\title{
Diversity among isolates of cowpea severe mosaic virus infecting cowpeas in northeastern Brazil
}

\author{
E.F.M. Abreu ${ }^{1,2}$, M.L.P. Tinoco ${ }^{3}$, E.C. Andrade $^{1}$ and F.J.L. Aragão ${ }^{3}$ \\ ${ }^{1}$ Embrapa Mandioca e Fruticultura, Cruz das Almas, BA, Brasil \\ ${ }^{2}$ Departamento de Biologia Celular, Universidade de Brasília, \\ Campus Universitário Darcy Ribeiro, Brasília, DF, Brasil \\ ${ }^{3}$ Embrapa Recursos Genéticos e Biotecnologia, Brasília, DF, Brasil \\ Corresponding author: F.J.L. Aragão \\ E-mail: aragao@cenargen.embrapa.br
}

Genet. Mol. Res. 11 (3): 3146-3153 (2012)

Received September 21, 2011

Accepted April 27, 2012

Published September 3, 2012

DOI http://dx.doi.org/10.4238/2012.September.3.3

\begin{abstract}
Eleven isolates of cowpea severe mosaic virus (CPSMV), a member of the genus Comovirus, were selected from 50 samples collected of nine cowpea fields in Northeastern Brazil (Piauí, Ceará, Rio Grande do Norte, Paraíba, Pernambuco, Alagoas, Sergipe, Bahia, and Distrito Federal) and partially sequenced. The RNA1 partial sequence, corresponding to the helicase, viral genome-linked protein, picornain 3C-like protease, and the RNA-directed RNA polymerase genes from CPSMV, had high identity among isolates, varying from 98 to $100 \%$. No evidence was found for intermolecular or intramolecular recombination. Phylogenetic analysis confirmed that the Brazilian CPSMV isolates are substantially different from the CPSMV strain USA. Despite the low variability found among Brazilian CPSMV isolates, there were notable differences in the symptomatology of infected cowpea plants, ranging from mild to moderate. Previous reports have demonstrated an association between CPSMV symptom determinants and helicase. However, we found no correlation between the helicase
\end{abstract}


mutations and symptoms caused by CPSMV. Nevertheless, all isolates with mutation $\mathrm{R}$ to $\mathrm{K}$ in the protease provoked severe symptoms. This type of information can provide a foundation for the development of strategies to produce durable resistant cowpea lines. It is crucial for strategies based on DNA sequence-dependent technologies, such as inhibition with RNAi.

Key words: Cowpea; Cowpea severe mosaic virus; Diversity; Brazil

\section{INTRODUCTION}

Cowpea (Vigna unguiculata [L.] Walp) is an annual tropical grain legume that plays an important role in the nutrition of people in developing countries of the tropics and subtropics, especially in sub-Saharan Africa, Central Asia, and South America (Kareem and Taiwo, 2007). Because of its nutritional properties, the cowpea is mainly grown for grain production, either being dried or canned green for in natura consumption. It is an inexpensive source of vegetable protein and a hardy crop well adapted to relatively dry environments. Pathogenic organisms are largely responsible for significant losses in cowpea plantations, often severely reducing the cultivation of the crop in a number of regions. Among the vulnerabilities of the cowpea plant, those of viral etiology stand out: worldwide, approximately 20 viruses are reported to infect this crop naturally (Thottappilly and Rossel, 1985). One of the most important viruses that infect cowpea in Brazil is cowpea severe mosaic virus (CPSMV), which belongs to the family Secoviridae and genus Comovirus (Gonçalves and Lima, 1982; Booker et al., 2005; Lima et al., 2005a).

CPSMV consists of 2 molecules of single-stranded RNA: positive sense, called RNA1, and RNA2. The genomic RNAs have a small basic protein (viral genome-linked protein $[\mathrm{VPg}]$ ) covalently linked to their 5'-termini and are polyadenylated at the 3'-end (Chen and Bruening, 1992). The CPSMV genome is expressed via the synthesis and proteolytic processing of a polyprotein precursor. CPSMV RNA1 codes for five mature proteins required for replication (from $5^{\prime}$ to 3 ', a protease cofactor, a putative helicase [Hel], a VPg, a protease [Pro], and a putative RNA-dependent RNA polymerase), whereas RNA2 codes for a putative cell-to-cell movement protein and two coat proteins (Lomonossoff and Ghabrial, 2001; Le Gall et al., 2005). CPSMV is easily transmitted mechanically, and in nature it is spread in a semi-persistent manner by several Chrysomelidae beetles, among them Ceratomia arcuata, the most important vector in Brazil (Costa et al., 1978; Lima et al., 2005b).

An interesting alternative for the control of CPSMV is the use of resistant cultivars. An attractive strategy would be to use engineered transgenic plants with the RNA interference (RNAi) concept to silence viral genes (Bonfim et al., 2007). The use of inverted repeat constructs, which result in double-stranded RNA transcripts, is the most efficient means of generating transformed lines showing effective gene knockdown or virus resistance (Aragão and Faria, 2009). However, RNAi is a sequence-specific gene-silencing mechanism. Consequently, information about virus genome variability is crucial. Despite numerous studies on viruses infecting cowpeas, information on virus diversity and genome variability is limited (Beserra Jr. et al., 2011). In this study, we partially sequenced isolates of CPSMV in northeastern Brazil, in which cowpea is a staple food for approximately 68 million people and the cultivation area comprises 1.3 million hectares. 


\section{MATERIAL AND METHODS}

\section{Virus isolates}

Plants with various levels of CPSMV symptoms were collected in 9 States of Brazil (Piauí, Ceará, Rio Grande do Norte, Paraíba, Pernambuco, Alagoas, Sergipe, Bahia, and Distrito Federal). During collection, the leaf samples were placed immediately in plastic bags containing moistened paper, transported to the laboratory in a Styrofoam box with ice packs, and stored at $-80^{\circ} \mathrm{C}$ until use. The geographic origins of the CPSMV isolates are shown in Figure 1.

\section{RNA extraction and RNA1 sequencing}

Total RNA was extracted from infected tissues using the Trizol reagent (Invitrogen, Carlsbad, CA, USA) and used to synthesize complementary DNA fragments with reverse transcriptase-polymerase chain reaction (RT-PCR) using Superscript ${ }^{\mathbb{R}}$ III Reverse Polymerase (Invitrogen). The RNA1 genomic segment from CPSMV was partially amplified with PCR using the primers CSMVF2000 (5'-GAGAAGGGAATGCACTTTGATT-3') and CSMVR4400 (5'-AGATTATATTCCATAGGAAGTA-3') and Taq Platinum DNA polymerase (Invitrogen). The amplified 2200-nucleotide fragment corresponded to the Hel, VPg, Pro coding sequences, and the partial sequence of the RNA-dependent RNA polymerase. PCR amplification was performed with an initial heating at $94^{\circ} \mathrm{C}$ for 3 min followed by 40 cycles of denaturation $\left(94^{\circ} \mathrm{C} / 1 \mathrm{~min}\right)$, annealing $\left(50^{\circ} \mathrm{C} / 1 \mathrm{~min}\right)$, and extension $\left(68^{\circ} \mathrm{C} / 4 \mathrm{~min}\right)$, and a final extension at $68^{\circ} \mathrm{C}$ for $10 \mathrm{~min}$. Amplified PCR products were directly sequenced by Macrogen Inc. (Seoul, Korea). The partial RNA1 sequences obtained were deposited in GenBank under accession Nos. JN652787 through JN652797.

\section{RNA dot-blot}

Total RNA was extracted from infected plants using a TRIzol RNA Purification Kit (Invitrogen). The RNA $(50 \mu \mathrm{g})$ was resuspended in $1 \mathrm{mM}$ ethylenediaminetetraacetic acid, $\mathrm{pH}$ 8.0 , to a final volume of $50 \mathrm{~mL}$. To this solution it was added $30 \mathrm{~mL} 20 \mathrm{X} \mathrm{SSC}$ and $20 \mathrm{~mL} 37 \%$ formaldehyde. The samples were incubated for $30 \mathrm{~min}$ at $60^{\circ} \mathrm{C}$ and kept on ice until transfer to a nylon membrane. Hybridization was carried out as described elsewhere (Bonfim et al., 2007). The probe was obtained from the Taíba-CE CPSMV isolate cloned into the pGEMT Easy Vector (Promega) and digested with EcoRI and HindIII to generate a 165-bp fragment.

\section{Sequence analyses}

Nucleotides and amino acid sequences were aligned using ClustalW. Phylogenetic analysis was performed with Mega 5 (Tamura et al., 2011) using the Kimura 2 parameter model for estimating genetic distances. A phylogenetic tree was obtained using the maximum likelihood algorithm with 1000 bootstrap replicates. This study compared the nucleotide and amino acid sequences individually with previously reported isolates of the same species or with isolates of the same genus (sequences were retrieved from the GenBank) to determine the relationship among Brazilian CPSMV isolates. 


\section{RESULTS AND DISCUSSION}

Fifty samples were collected from commercial cowpea fields in 9 Brazilian States (Piauí, Ceará, Rio Grande do Norte, Paraíba, Pernambuco, Alagoas, Sergipe, Bahia, and Distrito Federal; see Figure 1). All samples were screened for the presence of CPSMV through RNA blot analysis. The results revealed that $50 \%$ of the samples were positive (data not shown). Eleven isolates were chosen for sequencing based on the symptoms and cultivated area in each region (see Figure 1). A 2200-nucleotide sequence was produced, corresponding to the Hel, VPg, picornain Pro, and RNA-directed RNA polymerase genes from CPSMV. The sequencing of RNA1 reverse transcriptase PCR products from the total RNA extracted revealed high identity varying from 98 to $100 \%$ (Table 1). A sample of the isolate from Brazlândia-DF revealed $100 \%$ identity compared with an isolate from Taíba-CE, the sites of which are $1800 \mathrm{~km}$ apart. The amino acid identity was also high, varying from 96 to $100 \%$. Similar results were observed for isolates of the bean pod mottle virus (BPMV) infecting Desmodium illinoense in the United States. Nucleic acid identity of 99.4 to $100 \%$ was observed, with a predicted amino acid similarity varying from 98.5 to $99.4 \%$ in a fragment from RNA1 (Bradshaw et al., 2011). In addition, a recent study determined that the variability in 521 nucleotides from the coat protein gene of six isolates collected over a period of 32 years from CPSMV was very low, ranging from 97 to $100 \%$ nucleic acid identity and from 92 to $100 \%$ in the predicted amino acid sequences (Beserra Jr. et al., 2011).

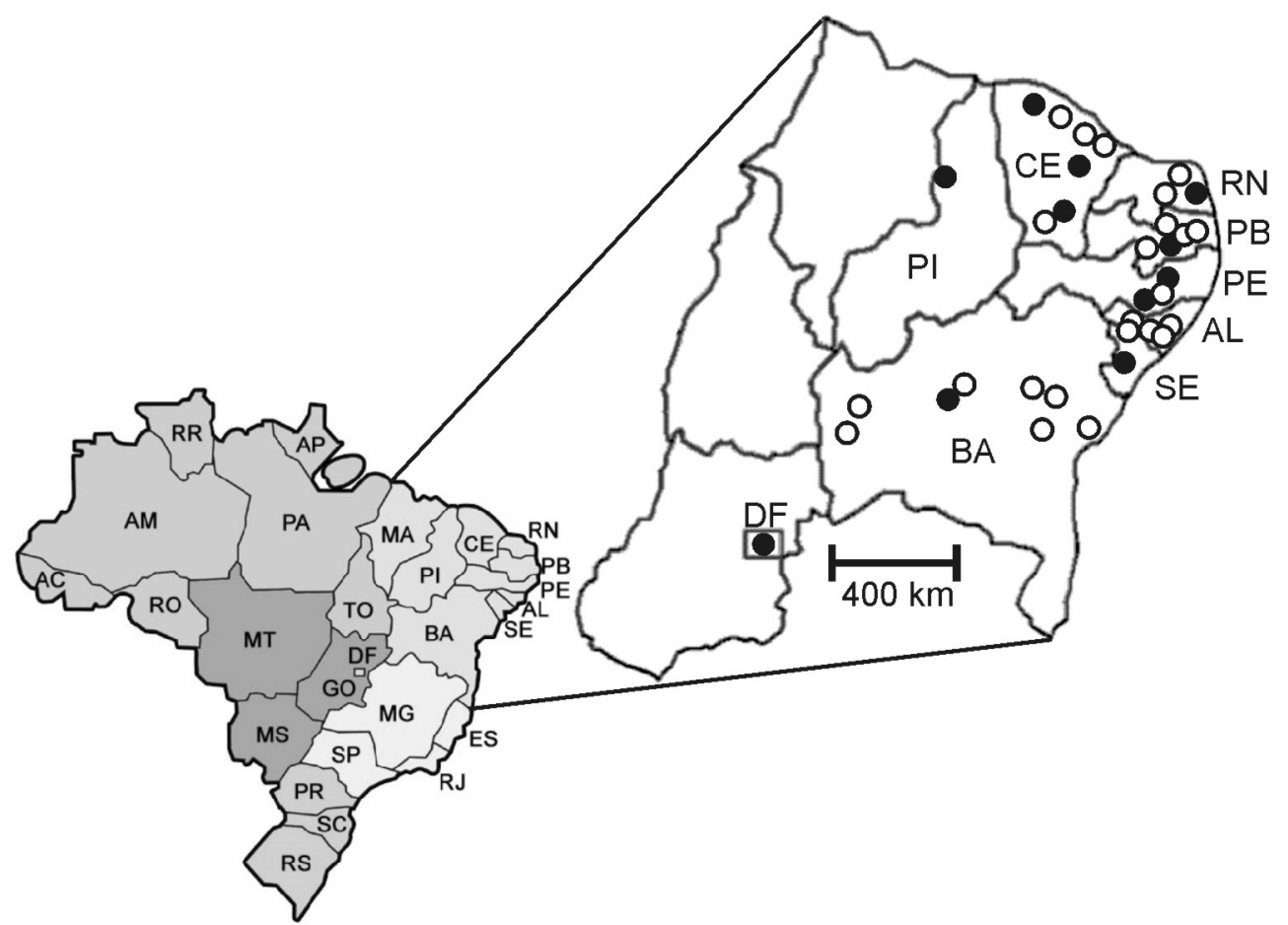

Figure 1. Map indicating municipalities where samples were collected (open circles) and those that were sequenced (filled circles). 
Table 1. Percent nucleotide (above diagonal) and deduced amino acid (below diagonal) sequence identity of a fragment from RNA1 (2200 nucleotides) of 11 Brazilian CPSMV isolates.

\begin{tabular}{|c|c|c|c|c|c|c|c|c|c|c|c|}
\hline & TAI & TAQ & TER & QUE & ITA & LAR & BRA & JAG & RUS & JUP & IRE \\
\hline TAI & & 98 & 100 & 98 & 98 & 98 & 98 & 98 & 98 & 98 & 98 \\
\hline TAQ & 97 & & 98 & 100 & 99 & 99 & 100 & 100 & 99 & 99 & 99 \\
\hline TER & 100 & 97 & & 98 & 98 & 98 & 98 & 98 & 98 & 98 & 98 \\
\hline QUE & 97 & 100 & 97 & & 99 & 99 & 100 & 99 & 99 & 99 & 99 \\
\hline ITA & 97 & 100 & 97 & 100 & & 99 & 99 & 99 & 100 & 100 & 100 \\
\hline LAR & 97 & 99 & 96 & 99 & 99 & & 99 & 99 & 99 & 99 & 99 \\
\hline BRA & 97 & 100 & 97 & 100 & 100 & 99 & & 100 & 99 & 99 & 99 \\
\hline JAG & 97 & 100 & 97 & 100 & 100 & 99 & 100 & & 99 & 99 & 99 \\
\hline RUS & 97 & 100 & 97 & 100 & 100 & 99 & 100 & 100 & & 100 & 100 \\
\hline JUP & 97 & 100 & 97 & 100 & 100 & 99 & 100 & 100 & 100 & & 99 \\
\hline IRE & 97 & 100 & 97 & 100 & 100 & 99 & 99 & 99 & 100 & 100 & \\
\hline
\end{tabular}

TAI = Taíba, CE; TAQ = Taquaritinga do Norte, PE; TER = Teresina, PI; QUE = Queimadas, PB; ITA = Itabaianinha, SE; LAR = Laranjeira do Abdias, RN; BRA = Brazlândia, DF; TAG = Jaguaribe, CE; RUS = Russas, CE; JUP = Jupi, PE; IRE = Irecê, BA.

Zhang et al. (2007) observed the presence of chimeric and mosaic RNA1 recombinants in the BPMV infecting soybean. In this study, we found no evidence for either intermolecular or intramolecular recombination in the RNA1 from CPSMV. Considering the fact that we analyzed isolates collected in distinct places distributed over an area of $1.2 \mathrm{million} / \mathrm{km}^{2}$, we believe that the variability in CPSMV in Brazil is low, which encourages us to use strategies based on RNAi for obtaining transgenic plants resistant to CPSMV that could be used throughout the extensive area in which cowpea is grown in Brazil.

Phylogenetic analysis confirmed that the Brazilian CPSMV isolates are substantially different from CPSMV strain DG (Figure 2). The robustness of the resulting phylogeny was evaluated with bootstrap analysis. An additional analysis with the partial RNA1-encoded polyprotein revealed a clear separation between isolates from Taíba-CE, Irecê-BA, and Teresina-PI, which formed a clade separate from the other Brazilian isolates. Nevertheless, no biological contrasts could be associated with this separation.

Despite the low level of variability among Brazilian CPSMV isolates, a notable difference in the symptomatology of infected cowpea plants occurs, ranging from mild to moderate. To determine host responses to the CPSMV isolates, symptoms in infected cowpea plants were compared using a scale from + (mild) to ++++ (severe). For BPMV, symptom determinants have been associated with the protease cofactor and Hel from BPMV RNA1 (Gu and Ghabrial, 2005). We found no correlation between mutations in Hel and symptoms caused by CPSMV, but all isolates with the protease mutation $\mathrm{R}$ to $\mathrm{K}$ presented severe symptoms (Figure 3 ). Complete sequences from the virus genome should be analyzed further to understand better the association between amino acid/protein structure variation and symptoms.

The results of the present study enhance observations regarding naturally occurring genetic diversity among CPSMV isolates, which is important for understanding the biology of the virus population and provides a basis for understanding the difficulty in identifying host resistance for disease control. In addition, this study provides information that will be the foundation for the development of strategies to produce durable, resistant lines. This information is even more crucial for strategies based on sequence-dependent technologies such as RNAi. Experiments are ongoing to generate transgenic cowpea plants resistant to CPSMV. 

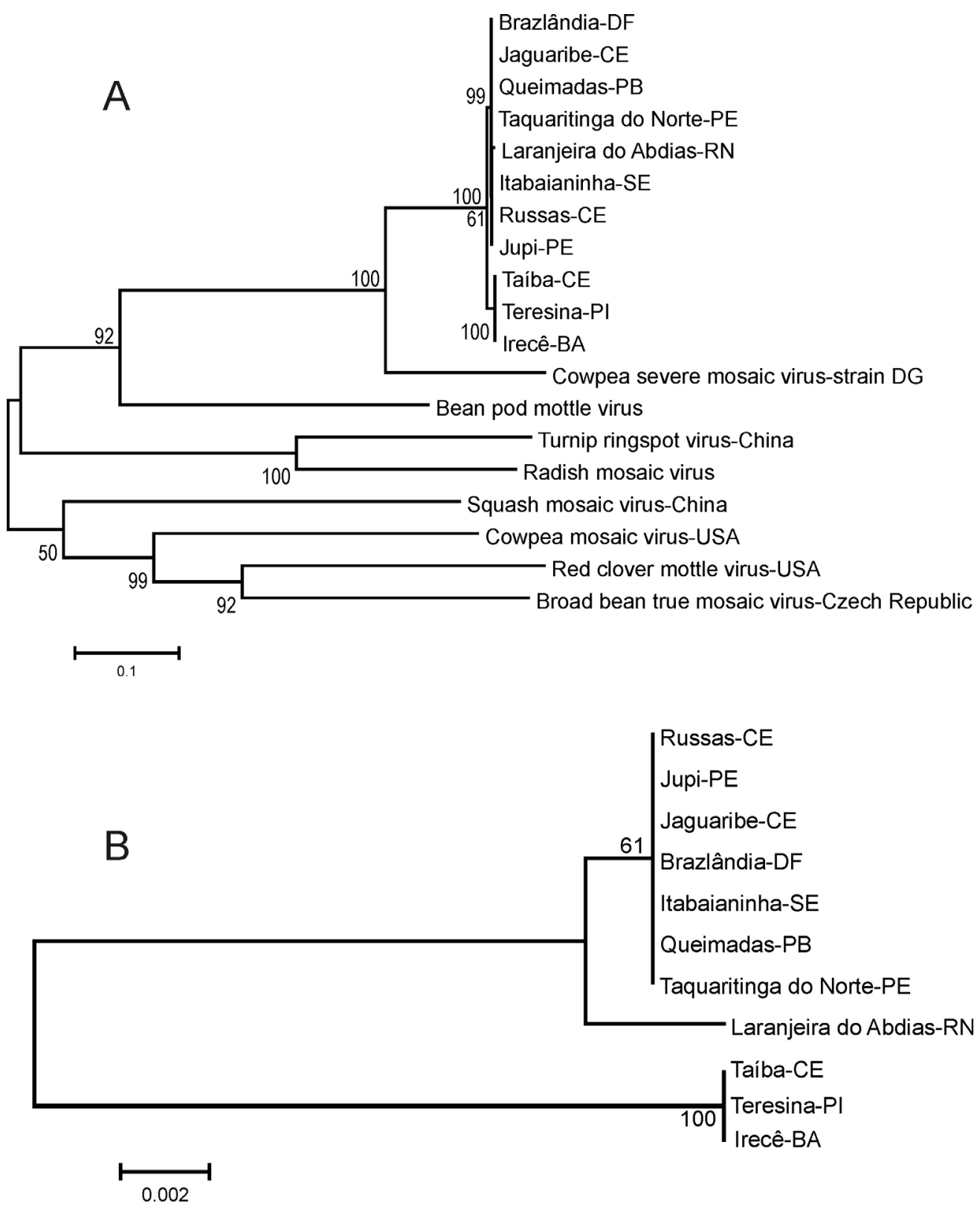

Figure 2. A. Maximum-likelihood tree of cowpea severe mosaic virus isolates and species from Comovirus genus based on 2200 nucleotides from RNA1. Correspondent sequences from Comovirus species were retrieved from GenBank accessions X00206 (cowpea mosaic virus), AY744932 (bean pod mottle virus), GU968732 (turnip ringspot virus), X64886 (red clover mottle virus), EU450837 (radish mosaic virus), GU810903 (broad bean true mosaic virus), M83830 (cowpea severe mosaic virus), and EU421059 (squash mosaic virus). Bootstrap values are of 1000 replicates and are expressed at nodes. B. There is a bootstrap consensus phylogenetic tree of the partial RNA1-encoded polyprotein from 11 Brazilian CPSMV isolates. 


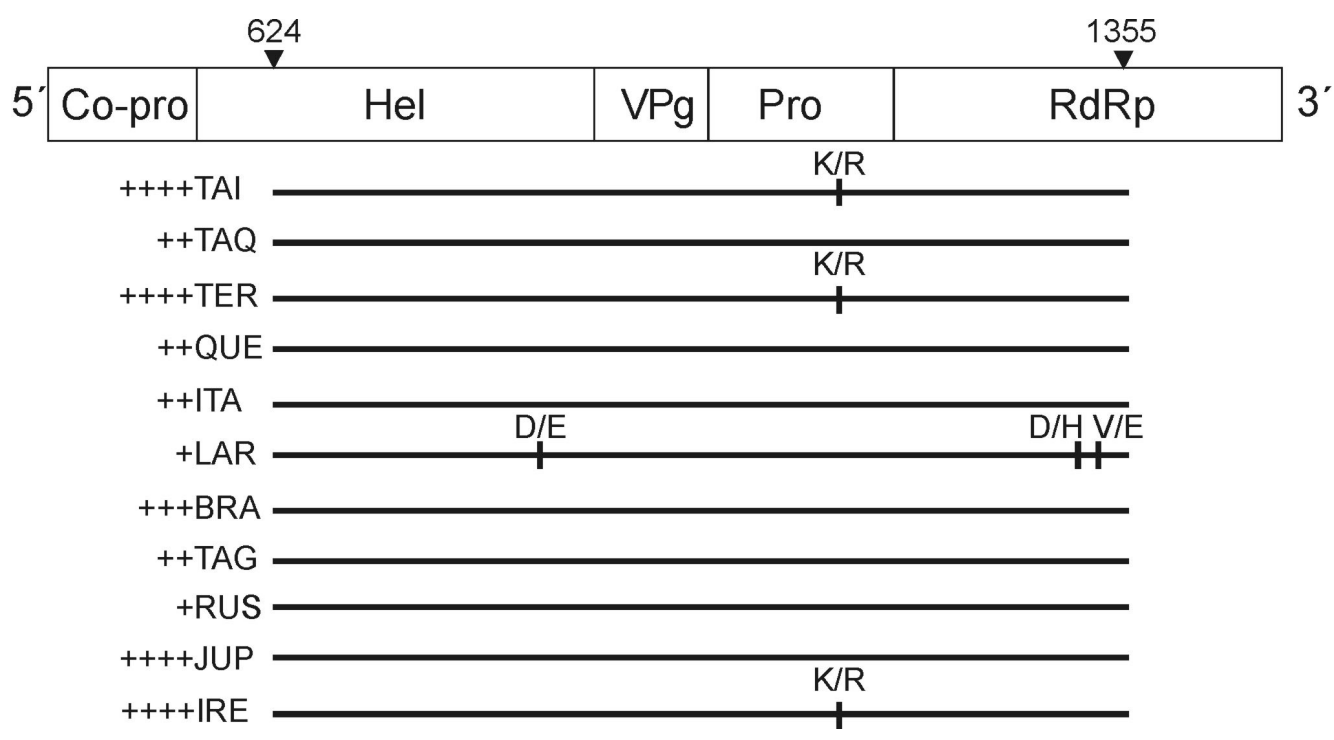

Figure 3. Distribution of divergence as compared to the consensus sequence of cowpea field isolates for the partial RNA1-encoded polyprotein from cowpea severe mosaic virus corresponding to helicase (Hel), viral genome-linked protein (VPg), picornain 3C-like protease (Pro), and RNA-directed RNA polymerase (RdRp) (amino acid 624 to 1355). A diagram of CPSMV RNA1 genome organization is shown at the top. Vertical lines indicate amino acid substitutions and symptom severity provoked by infection, with each isolate scored by + (mild) to ++++ (severe). Isolates are designed by: TAI = Taíba, CE; TAQ = Taquaritinga do Norte, PE; TER = Teresina, PI; QUE $=$ Queimadas, PB; ITA = Itabaianinha, SE; LAR = Laranjeira do Abdias, RN; BRA = Brazlândia, DF; TAG = Jaguaribe, CE; RUS = Russas, CE; JUP = Jupi, PE; IRE = Irecê, BA; E = glutamic acid; H = histidine; $\mathrm{K}=$ lysine; $\mathrm{R}=$ arginine; $\mathrm{V}=$ valine.

\section{ACKNOWLEDGMENTS}

We thank Joaquim A.A. de Oliveira for help in collecting cowpea samples. E.F.M. Abreu was the recipient of a fellowship from Conselho Nacional de Desenvolvimento Científico e Tecnológico.

\section{REFERENCES}

Aragão FJ and Faria JC (2009). First transgenic geminivirus-resistant plant in the field. Nat. Biotechnol. 27: 1086-1088. Beserra JEA Jr, Andrade EC, Camarço RFRA, Nascimento AKQ, et al. (2011). Sequence variability in the coat protein gene of cowpea severe mosaic virus isolates from northeastern Brazil. Trop. Plant Pathol. 36: 121-124.

Bonfim K, Faria JC, Nogueira EO, Mendes EA, et al. (2007). RNAi-mediated resistance to bean golden mosaic virus in genetically engineered common bean (Phaseolus vulgaris). Mol. Plant Microbe Interact. 20: 717-726.

Booker HM, Umaharan P and McDavid CR (2005). Effect of cowpea severe mosaic virus on crop growth characteristics and yield of cowpea. Plant Dis. 89: 515-520.

Bradshaw JD, Zhang C, Hill JH and Rice ME (2011). Landscape epidemiology of bean pod mottle Comovirus: molecular evidence of heterogeneous sources. Arch. Virol. 156: 1615-1619.

Chen X and Bruening G (1992). Cloned DNA copies of cowpea severe mosaic virus genomic RNAs: infectious transcripts and complete nucleotide sequence of RNA 1. Virology 191: 607-618.

Costa CL, Lin MT, Kitajima EW, Santos AA, et al. (1978). Cerotoma arcuata (Oliv.), um crisomelídeo vector do mosaico

Genetics and Molecular Research 11 (3): 3146-3153 (2012) CFUNPEC-RP www.funpecrp.com.br 
da Vigna no Brasil. Fitopatol. Bras. 3: 81-82.

Gonçalves MF and Lima JAA (1982). Efeitos do "cowpea severe mosaic virus" sobre a produtividade do feijão-de-corda. Fitopatol. Bras. 7: 547.

$\mathrm{Gu} \mathrm{H}$ and Ghabrial SA (2005). The Bean pod mottle virus proteinase cofactor and putative helicase are symptom severity determinants. Virology 333: 271-283.

Kareem KT and Taiwo MA (2007). Interactions of viruses in cowpea: effects on growth and yield parameters. Virol. J 4: 15.

Le Gall O, Iwanami T and Karasev AV (2005). Family Comoviridae. In: Virus Taxonomy. Eighth Report of the International Committee on Taxonomy of Viruses (Fauquet CM, Mayo MA, Maniloff J, Desselberger U, et al., eds.). Elsevier Academic Press, San Diego, 807-818.

Lima JAA, Sittolin IM and Lima RCA (2005a). Diagnose e Estratégias de Controle de Doenças Ocasionadas por Vírus. In: Feijão-Caupi Avanços Tecnológicos (Freire Filho FR, Lima JAA and Ribeiro VQ, eds.). Embrapa Informação Tecnológica, Brasília, 403-459.

Lima JAA, Nascimento AKQ, Silva GS, Camarço RFEA, et al. (2005b). Crotalaria paulinea, a new natural host of cowpea severe mosaic virus. Fitopatol. Bras. 30: 429-433.

Lomonossoff GP and Ghabrial SA (2001). Comoviruses. In: Encyclopedia of Plant Pathology (Maloy OC and Murray TD, eds.). John Wiley and Sons, New York, 239-242.

Tamura K, Peterson D, Peterson N, Stecher G, et al. (2011). MEGA5: molecular evolutionary genetics analysis using maximum likelihood, evolutionary distance, and maximum parsimony methods. Mol. Biol. Evol. 4: 1-9.

Thottappilly G and Rossel HW (1985). Worldwide Occurrence and Distribution of Virus Diseases. In: Cowpea Research, Production and Utilization (Singh SR and Richie KO, eds.). Jonh Wiley \& Sons, Chichester, 155-171.

Zhang C, Gu H and Ghabrial SA (2007). Molecular characterization of naturally occurring RNA1 recombinants of the Comovirus bean pod mottle virus. Phytopathology 97: 1255-1262. 